\title{
Pemanfaatan eXe Learning Sebagai Media Belajar Dari Rumah Selama Pandemi Covid-19
}

\author{
Mukhlis Rohmadi \\ mukhlis.rohmadi@gmail.com \\ IAIN Palangka Raya, Indonesia
}

Received: April 2021

Accepted: Juni 2021

Online Published: Juli 2021

\begin{abstract}
The Covid-19 pandemic has a profound impact on everything in the world. In education, learning that is not carried out face-to-face, so that media is needed to carry out for Online learning. eXe Learning is a distance learning media creation application that is very easy to use and operate. So that SD Muhammadiyah Pahandut uses eXe Learning as a learning medium in Online learning. The purpose of this research is to describe the use of eXe Learning applications as distance learning media. This research was conducted qualitatively. The resulting data were analyzed descriptively qualitatively to findings of the implementation of eXe Learning application as a distance learning medium. The results showed that eXe Learning as learning media could be quite effective, but some are too simple, and the content is incomplete. However, the media used has had a positive impact on the implementation of learning from home. For this reason, the use of this learning will manifest in the following semester.
\end{abstract}

Keywords: Learning Media, eXe Learning, Pandemic

Abstrak

Pandemi Covid-19 sangat berdampak pada semua hal di dunia ini. Dalam bidang pendidikan, pembelajaran yang dilaksanakan tidak dimungkinkan dilaksanakan tatap muka luring, sehingga diperlukan media untuk melaksanakan pembelajaran secara daring. eXe Learning merupakan aplikasi pembuatan media belajar jarak jauh secara daring yang sangat mudah penggunaan dan operasionalnya. Sehingga di SD Muhammadiyah Pahandut memanfaatkan eXe Learning sebagai media dalam pembelajaran di sekolah secara daring. Tujuan dari penelitian ini adalah untuk mendeskripsikan pemanfaatan aplikasi eXe Learning sebagai media belajar jarak jauh. Penelitian ini dilaksanakan secara kualitatif. Data yang dihasilkan dianalisis secara deskriptif kualitatif atas temuan pelaksanaan pemanfaatan aplikasi eXe Learning sebagai media belajar jarak jauh. Hasil penelitian menunjukkan bahwa media belajar $e X e$ Learning dapat dikatakan cukup efektif namun masih ada beberapa kekurangan diantaranya tampilan yang terlalu sederhana dan isi kurang lengkap. Namun demikian media yang digunakan cukup memberikan dampak positif dalam pelaksanaan pembelajaran daring dari rumah. Untuk itu pemanfaatan eXe Learning ini akan dilanjutkan pada semester berikutnya.

Kata kunci: Media Belajar, eXe Learning, Pandemi

\section{PENDAHULUAN}

Pendidikan merupakan proses perubahan diri seseorang. Belajar merupakan suatu proses interaksi terhadap segala situasi yang ada (Sudjana, 2014). Dalam kegiatan belajar mengajar, guru bertanggung jawab dalam pengorganisasian pengalaman belajar, penilaian proses dan hasil belajar. Setiap proses belajar mengajar yang berlangsung, transfer tidak dapat terlaksana tanpa adanya interaksi kuat antara Guru dan peserta didik. Proses transfer ilmu yang dilaksanakan akan lebih efektif jika dilaksanakan secara langsung berhadapan dan interaksi di 


\section{Educatio: Jurnal IImu Kependidikan}

Vol. 16, NNo 1 Juli 2021, hal. 37-49

http://e-journal.hamzanwadi.ac.id/index.php/edc

e-ISSN: 2527-9998 DOI: 10.29408/edc.v16i1.3343

kelas. Namun kondisi pandemi Covid-19 yang masuk ke Indonesia sejak Februari 2020 telah memaksa perubahan besar dalam hal sosial, termasuk juga proses belajar mengajar di sekolah. Proses pembelajaran sendiri memiliki beberapa tipe. Beberapa tipe sistem pembelajaran tersebut diantaranya (1) pembelajaran langsung (di kelas), (2) Pembelajaran tidak langsung, bisa menggunakan siaran televisi, radio, jaringan internet dan lainnya, (3) Pembelajaran mandiri, (4) Pembelajaran berbasis proyek, seperti pembelajaran di laboratorium, pengalaman lapangan dan lainnya yang sejenis (Rohmadi dan Septiana, 2020)

Proses belajar mengajar yang semula dilaksanakan secara langsung di dalam kelas dan terjadi interaksi kuat antara Guru dan peserta didik terdampak pandemi Covid-19 sehingga tidak lagi bisa dilaksanakan sementara waktu. Proses belajar mengajar harus dilaksanakan secara tidak langsung tatap muka antara Guru dan peserta didik. Hal ini mengharuskan adanya perubahan gaya belajar dan mengajar yang selama ini dilakukan secara langsung. Pendidikan di masa depan akan lebih ditentukan oleh jaringan informasi yang memungkinkan interaksi dan kolaborasi, bukan fisik gedung sekolah (Mason R dalam Gusmiyati, 2019) Dengan demikian maka proses belajar mengajar yang dilaksanakan sangat memerlukan media pembelajaran yang mudah dan mampu untuk menjadi media belajar dan media ajar bagi Guru dan peserta didik.

Hal ini sejalan dengan perkembangan teknologi informasi yang semakin pesat. Inovasi pembelajaran selalu berkembang sejalan dengan perkembangan teknologi informasi utamanya adalah internet. Sebagaimana pendapat Rusefendi (2014) yang menyatakan bahwa pendidikan saat ini identik dengan teknologi dan inovasi beragam, mulai dari buku dan media atau alat pembelajaran berbasis teknologi informasi seperti notebook. Inovasi ini juga dilakukan untuk efektivitas waktu agar penyerapan materi pelajaran lebih cepat dan tepat sampai kepada siswa. Perkembangan teknologi ini sangat membawa perubahan kepada pengguna. Berbagai macam akses informasi dan hiburan dapat dilakukan melalui satu pintu sama, yaitu internet. (Qomariyah, 2009:2). Dengan akses internet maka informasi dan komunikasi mampu menembus tanpa batas ruang dan waktu.

Perkembangan internet ini dapat dimanfaatkan dalam bidang pendidikan sebagai media untuk pembelajaran jarak jauh. Ada beberapa media yang bisa digunakan untuk pembelajaran jarak jauh. Media berupa aplikasi video conferences yang memungkinkan pertemuan bersama banyak individu untuk penyampaian materi langsung, pembelajaran elektronik menggunakan modul elektronik, website pembelajaran, video pembelajaran dan berbagai media lainnya. Untuk dapat menyatukan berbagai jenis media yang ada tersebut maka diperlukan satu aplikasi yang mampu menampungnya. Metode dan media pembelajaran merupakan unsur penting dan utama dalam proses belajar mengajar, kedua unsur ini saling terkait. Pemilihan suatu metode akan mempengaruhi jenis metode yang seharusnya digunakan. 


\section{Educatio: Jurnal IImu Kependidikan}

Vol. 16, NNo 1 Juli 2021, hal. 37-49

http://e-journal.hamzanwadi.ac.id/index.php/edc

e-ISSN: 2527-9998 DOI: 10.29408/edc.v16i1.3343

Pada masa pandemi covid-19 ini, pembelajaran jarak jauh sangat pasti dilakukan dengan bantuan media yang bersifat Online atau berbasis teknologi informasi dan komunikasi. Salah satu yang dapat digunakan adalah eXe Learning. eXe Learning sendiri merupakan aplikasi dengan sifat kode terbuka (Open Source) yang bisa digunakan membuat E-learning tanpa harus mengetahui bahasa pemrograman HTML. Aplikasi eXe Learning bisa mengekspor konten yang dibuat menjadi paket konten E-Pub (Elektronik Publications), LMS (Learning Management System) dalam bentuk SCROM1.2, ataupun dalam bentuk sebuah direktori website. Aplikasi eXe Learning sendiri sangat memudahkan pengajar atau Guru dalam membuat E-learning tanpa perlu memiliki keahlian khusus dalam pemrograman HTML, XML ataupun program website lainnya. E-learning XHTML editor (eXe) adalah suatu program desain yang berbasis web dirancang untuk membantu para guru dan akademisi di dalam desain, pengembangan dan menampilkan pelajaran yang berbasis web dan mengajar bahan-bahan tanpa membutuhkan kemampuan khusus dalam HTML, XML atau kemampuan pemrograman aplikasi web (Mukhlas,2015).

Pembelajaran di sekolah sangat terdampak pandemi Covid-19, salah satunya adalah di SD Muhammadiyah Pahandut. Kondisi ini memaksa Guru dan siswa di SD Muhammadiyah Pahandut untuk menyesuaikan pembelajaran dengan sistem jarak jauh. Dalam prosesnya, pembelajaran di SD Muhammadiyah Pahandut masih dilaksanakan pembelajaran jarak jauh dengan sistem penugasan dan bantuan WA Grup. Namun pada evaluasi awal pembelajaran jarak jauh dengan penugasan dan WA Grup tersebut dirasa belum efektif dalam penyampaian materi pembelajaran. Belum tersedianya media pembelajaran jarak jauh saat awal pandemi maka perlu dibuat media berbasis eXe Learning dalam pelaksanaan pembelajaran jarak jauh. Dengan pemanfaatan $e X e$ Learning sebagai media belajar jarak jauh ini sangat diharapkan meningkatkan hasil belajar secara signifikan sebagaimana hasil penelitian yang dilaksanakan Ningrum, dkk (2020) yang menunjukkan peningkatan hasil belajar yang signifikan setelah digunakan $e X e$ Learning dalam proses pembelajaran yang dilaksanakan. Demikian pula dapat diharapkan dengan pemanfaatan eXe Learning ini, motivasi belajar siswa dapat meningkat dan dapat dilanjutkan pemanfaatannya sebagai penunjang proses pembelajaran. Namun demikian, masih ada kendala dalam eXe Learning yaitu tidak dapat digunakan sebagai alat evaluasi, hanya bisa digunakan untuk latihan soal/latihan evaluasi (Sepriadi, dkk, 2020).

Dari beberapa latar belakang masalah dan memperhatikan hasil pemanfaatan $e X e$ Learning yang digunakan oleh beberapa peneliti, maka dirasa sangat perlu untuk dilakukan pemanfaatan eXe Learning sebagai media belajar jarak jauh di SD Muhammadiyah Pahandut. Sejak semester ganjil 2020/2021, SD Muhammadiyah Pahandut telah menerapkan eXe Learning sebagai media belajar jarak jauh. Setelah berjalan selama 1 semester, atau tepatnya pada semester genap 2020/2021 maka dilakukan evaluasi pemanfaatan eXe Learning sebagai media belajar jarak jauh di SD Muhammadiyah Pahandut. Hal ini dilaksanakan untuk 
memperbaiki sistem pembelajaran yang dilaksanakan apakah dilanjutkan, perlu perubahan atau tambahan.

\section{METODE PENELITIAN}

Penelitian ini menggunakan penelitian kualitatif untuk memperoleh informasi yang mendalam mengenai pemanfaatan eXe Learning sebagai media belajar dari rumah di SD Muhammadiyah Pahandut Palangka Raya semester ganjil tahun pelajaran 2020/2021. Subjek penelitian ini adalah semua Guru, sebagian siswa, orang tua/wali siswa dan komite SD Muhammadiyah Pahandut Palangka Raya. Pada penelitian ini dilaksanakan di kelas 1 sampai dengan kelas 6 pada semua kelas dan semua mata pelajaran, mulai dari mata pelajaran Tematik, Kemuhammadiyahan, PJOK, Al Islam (PAI), Bahasa Inggris, Muatan Lokal, Matematika, TIK serta Bahasa Arab. Instrumen Pengumpulan Data yang digunakan dalam penelitian ini instrumen dokumentasi, angket dan lembar wawancara. Dalam analisa data, digunakan teknik analisis kualitatif deskriptif, hal ini dikarenakan penelitian ini bertujuan untuk mengetahui deskripsi pemanfaatan eXe learning sebagai media belajar. Untuk keabsahan data, digunakan teknik triangulasi data, yaitu untuk menghasilkan data yang tepat dan mantap.

\section{HASIL DAN PEMBAHASAN}

Media eXe Learning yang digunakan untuk pembelajaran menggunakan sub domain sekolah http://belajar.sdmp.sch.id/, dengan sebutan Web Belajar. Penyebaran angket awal untuk memperoleh tanggapan pemanfaatan eXe Learning sebagai media belajar jarak jauh diberikan kepada Guru, Komite Sekolah, Orang tua / Wali Siswa dan Siswa itu sendiri. Total responden yang bersedia mengisi angket sejumlah 182 responden dengan sebaran sebagaimana pada Gambar 1.

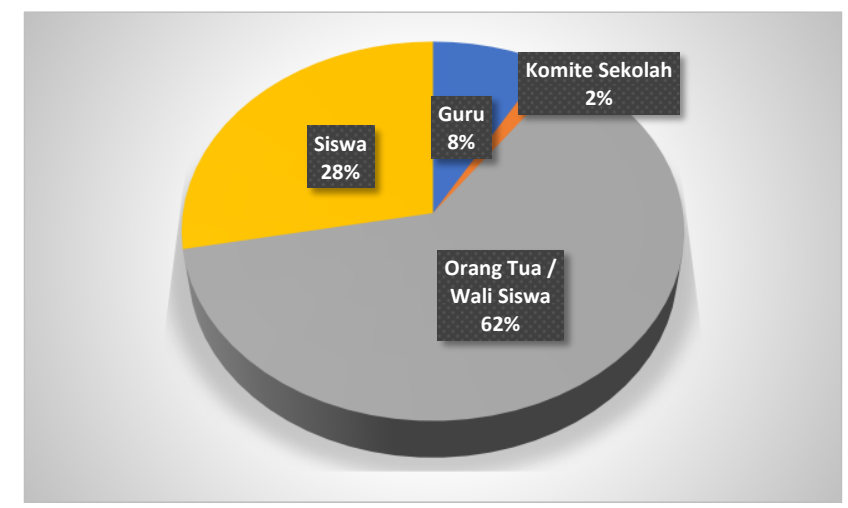

Gambar 1 Sebaran Responden Angket

Dari seluruh responden tersebut dapat ditampilkan data hasil per sebaran sebagai berikut: 


\section{Guru}

a. Persepsi Guru dalam membuat media berbasis eXe Learning

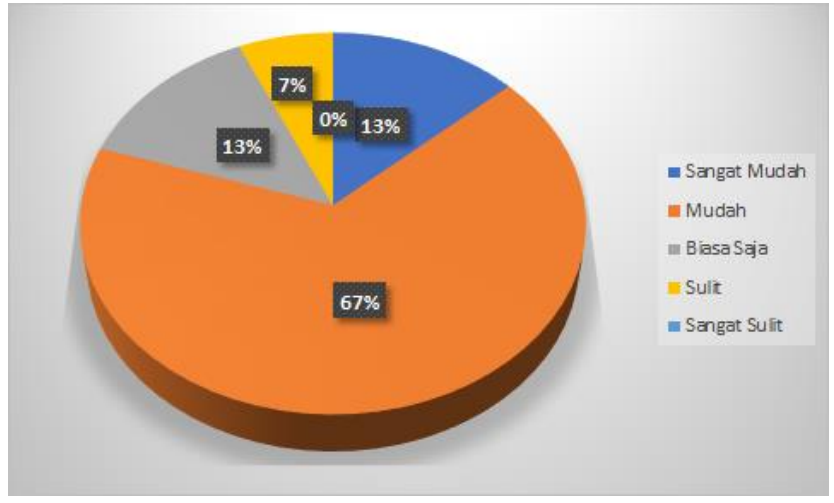

Gambar 2 Persepsi Guru membuat media berbasis eXe Learning

Dari keseluruhan persepsi, 1 orang responden Guru menjawab sulit dengan alasan "Aplikasi sering hang/berhenti mendadak saat digunakan"

b. Media yang paling banyak ditambahkan melalui eXe Learning

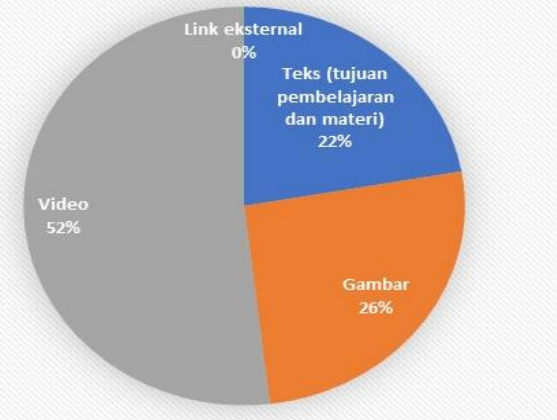

Gambar 3 Media yang ditambahkan dalam eXe Learning

Dari hasil yang didapatkan, mayoritas Guru menambahkan video pembelajaran. Video yang ditambahkan Guru, mereka menyatakan buatan sendiri $(86,67 \%)$ dan sisanya mengunduh dari aplikasi berbagi video Youtube. Banyak variasi aplikasi yang digunakan Guru dalam membuat video yang diunggah, terbanyak menggunakan aplikasi Camtasia Studio sebanyak $40 \%$. 


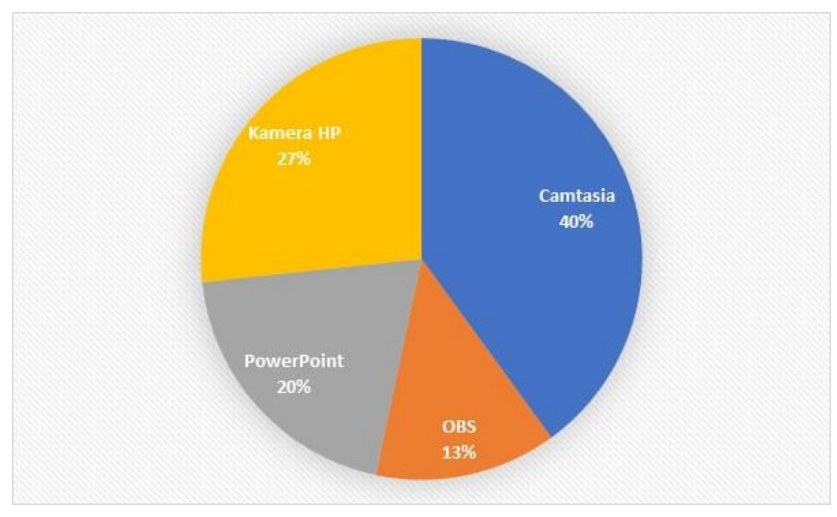

Gambar 4 Aplikasi / Sumber video untuk pembelajaran

c. Kesiapan Guru dalam menyediakan media pembelajaran berbasis eXe Learning

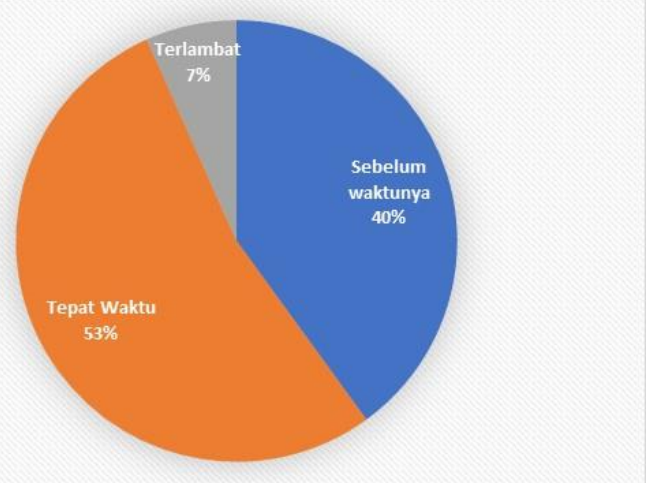

Gambar 5 Kesiapan Guru menyiapkan media eXe Learning

d. Monitoring Guru terhadap penggunaan web belajar oleh siswa

Monitoring Guru terhadap siswa dalam membuka web belajar, 93,33\% menyatakan memantau siswanya Dari hasil pantauan Guru, didapatkan keterangan bahwa ada 93,33\% Guru menyatakan siswa senang menggunakan web belajar. Serta 100\% Guru menyatakan siap melanjutkan web belajar dan memperbaiki jika masih ada yang kurang untuk keberlangsungan pembelajaran Online. Jika memang sudah offline dapat digunakan sebagai penunjang pembelajaran offline.

\section{Komite Sekolah}

a. $66,67 \%$ sering membuka web belajar SDMP dan 33,33\% jarang membuka

b. Mengenai aspek pemanfaatan web belajar, 66,67\% mengatakan sangat mudah operasionalnya dan 33,33\% mengatakan mudah

c. Masukan dari responden, sebaiknya materi dibuat lebih menarik dan bisa dipertahankan untuk pembelajaran berikutnya 


\section{Orang Tua / Wali Siswa}

a. $81 \%$ menyatakan mudah dalam akses web belajar

b. $81 \%$ menyatakan mudah operasional dalam akses web belajar

c. Pendapat orang tua/wali siswa mengenai tampilan web belajar

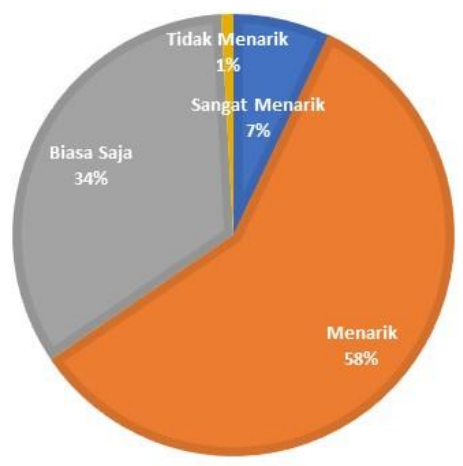

Gambar 6 Pendapat tentang tampilan web belajar

d. Perhatian orang tua/wali dalam pendampingan penggunaan web belajar

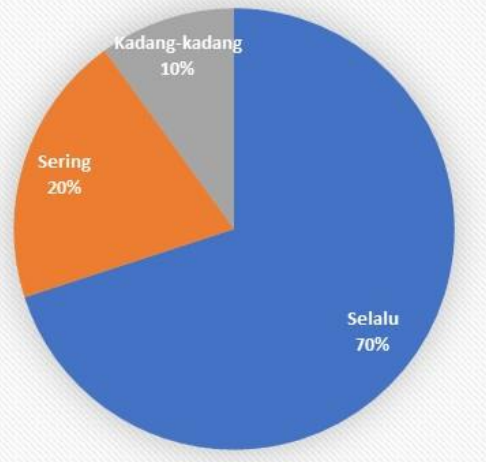

Gambar 7 Perhatian orang tua/wali dalam pendampingan belajar

e. Pemahaman siswa menurut orang tua terkait pembelajaran menggunakan web belajar

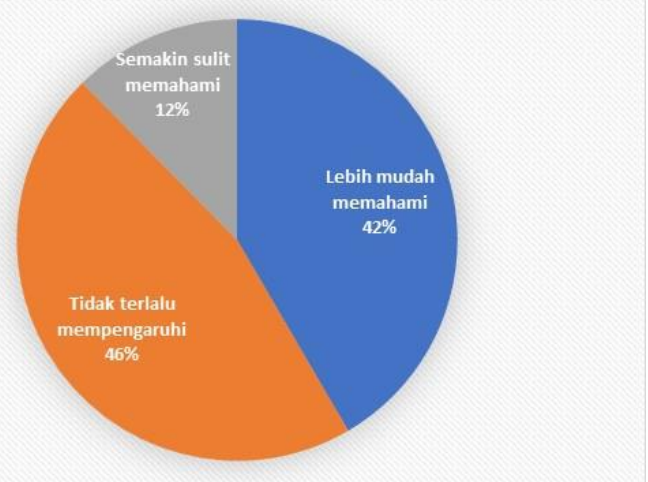

Gambar 8 Pemahaman belajar siswa menurut persepsi orang tua 
f. Terkait penggunaan web belajar ke depan sebagai pendukung pembelajaran offline, $70 \%$ orang tua menyatakan sependapat penggunaan web belajar, dan $30 \%$ menyatakan tidak sependapat penggunaan web belajar

i. Alasan dan pendapat jika tetap digunakan

- Sebagai pendukung belajar di rumah

- Ditambahkan latihan soal

- Video pembelajaran dibuat lebih menarik, diusahakan penjelasan oleh Guru bukan orang lain dan diberikan Link unduh

- Materi diperluas dan diberikan contoh

ii. Alasan dan pendapat jika tidak sependapat digunakan lagi

- Perlu aplikasi standar seperti video conferences

- Kurang efektif karena tidak tatap muka secara langsung

- Tidak konsisten waktu upload

- Anak sambil bermain game

- Sudah pembelajaran offline jadi tidak diperlukan lagi

- Anak tidak diperkenankan bermain gawai saat di rumah

\section{Siswa}

a. Frekuensi membuka web belajar SDMP

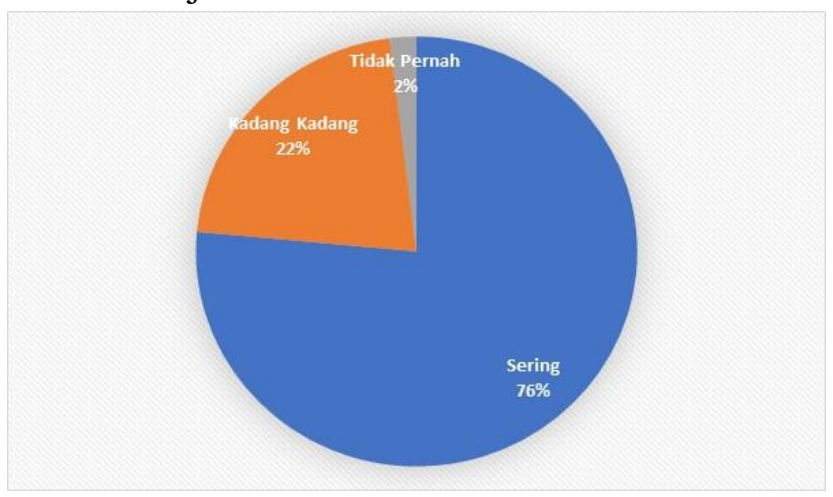

Gambar 9 Frekuensi membuka web belajar

b. Mengenai tampilan web belajar, $69 \%$ responden siswa menjawab tidak perlu perubahan, sedangkan sisanya $31 \%$ mengatakan perlu perubahan

c. $80 \%$ siswa mengatakan menjadi lebih mudah memahami materi dengan web belajar

d. $43 \%$ mengatakan lebih memilih buku dan web belajar, sedangkan $14 \%$ lebih memilih video

e. Web belajar masih diperlukan jika sudah masuk sekolah, 55\% menjawab tidak dan $45 \%$ menjawab ya 


\section{Educatio: Jurnal IImu Kependidikan}

Vol. 16, NNo 1 Juli 2021, hal. 37-49

http://e-journal.hamzanwadi.ac.id/index.php/edc

e-ISSN: 2527-9998

DOI: 10.29408/edc.v16i1.3343

\section{PEMBAHASAN}

Pembelajaran dari rumah atau daring yang dilaksanakan di SD Muhammadiyah Pahandut Palangka Raya dilaksanakan dengan pemanfaatan aplikasi eXe Learning yang dibuat menjadi web belajar. Web belajar ini dikembangkan secara cepat dan dilaksanakan dengan pelatihan kepada Guru dalam pemanfaatan dan pembuatannya. Aplikasi eXe Learning ini dipergunakan karena berdasarkan studi literatur diperoleh hasil bahwa aplikasi eXe Learning dapat menunjang pembelajaran siswa karena dapat digunakan kapan saja dan dimana saja serta mampu dijalankan baik dengan laptop maupun smartphone karena berbasis web (Fitriyani, dkk, 2020)

Hal ini dikarenakan kebijakan pembelajaran dari rumah yang mendadak akibat bencana Pandemi Covid-19. Persiapan yang sangat minimal dan cepat dilaksanakan untuk dapat memenuhi tuntutan pembelajaran dari rumah dan tetap terlaksananya bimbingan pembelajaran dari rumah.

Pemanfaatan web belajar yang menggunakan aplikasi eXe Learning ini mendapat respons dari berbagai pihak terkait yang menggunakannya. Mulai dari pihak Sekolah (Guru dan komite) hingga orang tua atau wali siswa dan siswa sendiri. Dalam sebaran hasil angket yang dipaparkan dalam hasil penelitian di atas, terlihat bahwa Guru merasa mudah dalam pengisian atau pembuatan web belajar menggunakan eXe Learning. Walaupun mudah dalam pembuatannya, namun dari hasil wawancara pada sebagian Guru, beberapa Guru belum atau tidak siap dalam pengisian aplikasi karena pelaksanaan pembelajaran dari rumah yang bersifat mendadak dan sebelumnya banyak yang tidak siap materi dalam bentuk elektronik. Dengan demikian, masih ada beberapa Guru yang terlambat dalam pengisian ataupun penyiapan web belajar. Ada beberapa Guru yang akhirnya memilih dengan mengisi web belajar dengan media video, baik video yang dibuat sendiri maupun diunduh dari penyedia lainnya seperti Youtube, dll.

Aplikasi eXe Learning merupakan open source yang menggunakan bahasa pemrograman HTML namun mudah digunakan walau pengguna tidak memahami bahasa pemrograman sekalipun (Machril, dkk, 2015). Selain mudah digunakan dalam pembelajaran, penggunaan media pembelajaran berbasis eXe Learning menurut Lubis dan Napitupulu (2016) juga dapat meningkatkan capaian hasil belajar. Pelaksanaan dan pemanfaatan web belajar ini memudahkan Guru dalam memberikan materi kepada siswa, namun sedikit kesulitan dalam pemantauan pemanfaatan oleh siswa. Hal ini sejalan dengan hasil penelitian dari Febryana, dkk (2020) yang menyatakan bahwa penggunaan eXe Learning dapat meningkatkan literasi dan hasil belajar siswa. Aplikasi ini tidak memberikan fitur View yang memperlihatkan siapa dan berapa kali membuka web belajar oleh siswa. Hal ini dikarenakan sederhananya fitur eXe Learning yang sederhana, berbasis $x H T M L$, jadi tidak mendukung perhitungan viewer. Namun Guru 


\section{Educatio: Jurnal IImu Kependidikan}

Vol. 16, NNo 1 Juli 2021, hal. 37-49

http://e-journal.hamzanwadi.ac.id/index.php/edc

e-ISSN: 2527-9998

DOI: 10.29408/edc.v16i1.3343

melaksanakan pemantauan siswa yang membuka web belajar dengan meminta foto untuk laporan dalam membaca dan mengerjakan tugas yang diberikan melalui web belajar. Beberapa siswa yang hampir tidak pernah membuka web belajar dapat terpantau dengan tidak mengerjakan tugas. Kondisi ini dilaksanakan solusi dengan memanggil orang tua atau wali siswa ke sekolah untuk dilakukan konfirmasi permasalahan yang dihadapi sehingga tidak dapat mengikuti pembelajaran.

Pelaksanaan pembelajaran dengan web belajar juga dipantau oleh Komite Sekolah. Hal ini dilakukan untuk dapat memastikan pembelajaran berlangsung semestinya. Unsur komite sekolah yang ada merupakan unsur dari Yayasan, Sekolah dan Orang Tua siswa. Dari pemantauan komite sekolah, menyatakan bahwa perlunya ditingkatkan tampilan dan isi dari web belajar. Hal ini disampaikan agar siswa lebih tertarik dalam proses belajar, dan memudahkan siswa dalam akses. Hal ini senada dengan masukan dari orang tua siswa dan beberapa siswa menyampaikan hal yang sama. Hal ini merupakan tantangan bagi guru untuk lebih membuat menarik tampilan pembelajaran dari web belajar. Dalam pembuatannya, $e X e$ Learning tidaklah sulit karena tidak perlu mengetahui bahasa pemrograman yang sulit.

Secara keseluruhan, media belajar eXe Learning yang digunakan di SD Muhammadiyah Pahandut ini belum sepenuhnya membantu proses belajar dari rumah. Hal ini dikarenakan pengembangan dan pengisian oleh guru yang belum maksimal akibat kurangnya pemahaman dan kesiapan materi untuk mengisi web belajar. Serta tidak dapat digunakan untuk memonitor siswa secara langsung dengan tatap muka, baik tatap muka luring maupun daring, sebagaimana apabila menggunakan video conferences. Namun demikian, Guru sudah mengusahakan dengan maksimal untuk memenuhi tuntutan dengan menyiapkan pembelajaran. Mayoritas orang tua maupun siswa merasa terbantu dengan adanya penggunaan web belajar berbasis $e X e$ Learning ini. Terlihat bahwa $56 \%$ orang tua siswa menyatakan web belajar menarik, walau perlu adanya perbaikan dari sisi tampilan dan isi untuk lebih diperkaya lagi. Hal ini selaras dengan pernyataan Sepriadi, dkk (2020) yang menyatakan bahwa tanggapan terhadap media pembelajaran $\mathrm{eXe}$ Learning adalah sangat positif, karena media pembelajaran tersebut menarik minat dan motivasi siswa dalam mengikuti pembelajaran yang ditunjukkan dengan cepatnya respons siswa terhadap informasi yang berkaitan dengan pelaksanaan pembelajaran e-learning. Senada dengan hal tersebut, Kepala Sekolah menyatakan bahwa sangat terbantu dengan adanya web belajar ini. Karena Kepala Sekolah juga lebih mudah memonitor Guru dalam melaksanakan pembelajaran jarak jauh kepada siswa. Efektivitas pembelajaran menggunakan eXe Learning ini dapat dikatakan belum terlalu efektif, karena dari pernyataan orang tua ataupun siswa masih banyak yang merasa belum cukup terbantu pembelajaran jarak jauh yang dilaksanakan dengan web belajar. Hal ini sedikit berbeda dengan hasil penelitian Febryana, NE, dkk (2021) yang menyatakan bahwa eXe Learning dinilai efektif untuk diimplementasikan guna meningkatkan kemampuan literasi sains siswa. Karena penggunaan media eXe Learning 


\section{Educatio: Jurnal IImu Kependidikan}

Vol. 16, No 1 Juli 2021, hal. 37-49

http://e-journal.hamzanwadi.ac.id/index.php/edc

e-ISSN: 2527-9998

DOI: 10.29408/edc.v16i1.3343

memiliki bahasa sifatnya komunikatif dan dapat berlangsung dua arah yang memudahkan siswa mempelajari suatu materi. Penyebab kurang efektif pada pemanfaatan eXe Learning di SD Muhammadiyah Pahadut ada beberapa aspek penyebab. Diantaranya adalah grade sekolah yang pada tingkatan Sekolah Dasar, sedangkan yang dilakukan Febryana pada grade Sekolah Lanjutan Tingkat Pertama (MTs), sehingga pada grade anak-anak SD belum terlalu membantu proses belajar mengajar, sesuai dengan kondisi psikologis anak SD jika memegang gawai maka membuka pembelajaran baru sesaat dan terganggu adanya game dll.

Dampak pembelajaran jarak jauh ini sangat terasa bagi siswa kelas 1 dan 2, dikarenakan mereka baru masuk sekolah sudah melaksanakan pembelajaran jarak jauh. Dari hasil wawancara dengan beberapa orang tua siswa dan siswa, mayoritas menyatakan sulit belajar dengan web belajar berbasis eXe Learning tersebut karena siswa kelas 1 dan 2 masih perlu bimbingan intensif mengenai cara membaca, mengenal dunia dan juga untuk bersosialisasi. Hal ini kurang sesuai dengan hasil penelitian Ningrum, dkk (2020) yang menyatakan hasil bahwa terdapat peningkatan yang signifikan hasil belajar kategori tinggi. Perbedaan ini terjadi dikarenakan perbedaan grade dan usia siswa yang diberikan media berbasis eXe Learning itu sendiri. Dalam perlakuan yang dilaksanakan Ningrum adalah pada siswa tingkat sekolah atas (MA) sedangkan pelaksaan web belajar ini diterapkan pada sekolah dasar. Kekurangan pemahaman dan kendala lainnya ditangani pihak sekolah dengan beberapa kali melakukan pembelajaran tatap muka virtual menggunakan Google meet atau Zoom. Namun tatap muka yang dilaksanakan tidak bisa maksimal juga karena beberapa hal, diantaranya ketersediaan perangkat dan kuota siswa. Maka dalam kondisi demikian, pendampingan melalui web belajar sangatlah diperlukan, untuk mengkomunikasikan materi dan penugasan serta latihan soal kepada siswa yang dapat dilaksanakan kapan saja dan di mana saja sepanjang siswa mampu melaksanakannya.

Ketertarikan siswa dalam pemanfaatan web belajar berbasis $e X e$ Learning ini juga terlihat dari frekuensi siswa dalam membuka web belajar. Bukan hanya pada saat ada materi namun setiap saat siswa membuka web belajar untuk mengetahui pembelajaran terbaru maupun mengulang pembelajaran yang telah lalu. Adanya peningkatan aktivitas belajar sesudah implementasi media eXe Learning sejalan dengan penelitian yang dilakukan oleh Muzijah, Wati, dan Mahtari (2020). Hasil belajar siswa pada semester ganjil 2020/2021 terlihat cukup memuaskan walaupun ada beberapa siswa masih kurang karena beberapa faktor. Hal ini dapat menggambarkan bahwa fungsionalitas eXe Learning yang digunakan cukup baik, membantu siswa yang kurang mampu ataupun tidak sempat membeli buku pembelajaran dapat belajar hal sama dengan teman lain yang memiliki buku. Oleh karena itu, pada semester berikutnya karena masih belajar dari rumah, web belajar masih digunakan untuk menunjang pembelajaran yang dilaksanakan disamping menggunakan aplikasi video conferences. 


\section{Educatio: Jurnal IImu Kependidikan}

Vol. 16, NNo 1 Juli 2021, hal. 37-49

http://e-journal.hamzanwadi.ac.id/index.php/edc

e-ISSN: 2527-9998

DOI: 10.29408/edc.v16i1.3343

\section{SIMPULAN}

Dari hasil penelitian di atas dapat disimpulkan bahwa pemanfaatan eXe Learning sebagai media belajar dari rumah cukup membantu siswa dan orang tua dalam belajar mandiri dengan pendampingan tidak langsung dari Guru. Pemanfaatan eXe Learning yang dilakukan oleh SD Muhammadiyah Pahandut dapat menambah motivasi dan hasil belajar siswa, hal ini terlihat dari frekuensi siswa dalam melihat web belajar. Namun demikian masih perlu perbaikan dan pembenahan pada beberapa hal dalam pemanfaatannya, diantaranya adalah segi tampilan dan isi untuk diperkaya lagi. Serta pemanfaatan eXe Learning ini akan tetap diterapkan dalam pembelajaran dari rumah pada semester berikutnya dan akan digunakan juga sebagai penunjang pembelajaran di kelas walaupun sekolah mulai tatap muka secara luring, namun hanya sebagai bahan belajar tambahan dari guru di sekolah. Dapat disarankan pula untuk beberapa sekolah bisa melaksanakan atau melakukan pengembangan media eXe Learning sebagai media belajar jarak jauh. Dengan demikian, hasil penelitian sudah didapatkan dengan hasil deskripsi pemanfaatan eXe Learning sebagai media belajar jarak jauh dan memberikan saran kelanjutan penggunaan aplikasi tersebut pada pembelajaran selanjutnya.

\section{PERNYATAAN PENULIS}

Penulis menyatakan bahwa artikel ini belum pernah diterbitkan dalam jurnal mana pun

\section{DAFTAR PUSTAKA}

D. Mukhlas. (2017). Tutorial Modul eXe Learning. Bandung : PT Remaja Rosdakarya.

Febryana, N. E., Septiana, N., \& Rohmadi, M. (2021). Literasi Sains Siswa Kelas IX Dengan Implementasi Media Pembelajaran Berbasis EXe Learning Pada Materi Pewarisan Sifat. Bioeduca : Journal of Biology Education, 3(1), 67-78. https://doi.org/10.21580/bioeduca.v3i1.6638

Fitriyani, Yuliani, H. \& Rohmadi, M 2020. Analisis Kebutuhan Media Pembelajaran Bermuatan Nilai-Nilai Karakter Islami Pada Materi Fisika | Fitriyani | Prosiding SNFA (Seminar Nasional Fisika dan Aplikasinya). (t.t.). Diambil 21 April 2021, dari https://jurnal.uns.ac.id/prosidingsnfa/article/view/78-84.

Gusmiyati, Hariyanti, Dedi., \& Zulfakar. (2019). Pendidikan Berbasis Teknologi: Permasalahan dan Tantangan. In Prosiding Seminar Nasional Pendidikan Program Pascasarjana Universitas Pgri Palembang.

Lubis, A., \& Napitupulu, E. (2016). Pengaruh Strategi Pembelajaran Dengan Penggunaan Media Exelearning dan Komunikasi Interpersonal terhadap Hasil Belajar IPA Siswa Kelas VIII SMP Negeri di Kecamatan lima puluh. Jurnal Teknologi Informasi \& Komunikasi dalam Pendidikan, 3(2). 
Machril, Sadzali Yunaifi, \& Darwin. (2015). Pengaruh Media Pembelajaran Exe (Elearning Xhtml Editor) terhadap Hasil Belajar Konstruksi Bangunan Kompetensi Keahlian Teknik Gambar Bangunan pada Siswa Kelas X SMK Negeri 5 Medan. Jurnal Education Building, 1(1).

Muzijah, R., Wati, M., \& Mahtari, S. (2020). Pengembangan E-modul Menggunakan Aplikasi Exe-Learning untuk Melatih Literasi Sains. Jurnal Ilmiah Pendidikan Fisika, 4(2), 89-98.

Ningrum, L. C., Rohmadi, M., \& Yuliani, H. (2020). Problem Based Learning Berbantuan Exe Learning Pada Materi Momentum Dan Impuls: Dampak Berpikir Kritis Dan Hasil Belajar. Prosiding Seminar Pendidikan Fisika FITK UNSIQ, 2(1), 274-279. Diambil dari https://ojs.unsiq.ac.id/index.php/semnaspf/article/view/1431/858

Qomariyah, A. N. (2009). Perilaku penggunaan internet pada kalangan remaja di perkotaan. Universitas Airlangga Surabaya.

Rohmadi, Mukhlis \& Septiana, Nurul. (2020). Persepsi Mahasiswa terhadap Pembelajaran Daring selama Masa Tanggap Darurat Covid-19. Prosiding Seminar Nasional Online Pembelajaran IPA dalam Masa Pandemik Covid-19, 16 Juni 2020, 72-80. Sekolah Pascasarjana Universitas Pakuan.

Ruseffendi, H. E. T. (2014) Perkembangan pendidikan matematika. Diambil dari https://www.pustaka.ut.ac.id/lib/mpmt5102-perkembangan-pendidikanmatematika/\#tab-id-3

Sepriadi, S., Rohmadi, M., \& Syar, N. I. (2020). Pengembangan Media Pembelajaran Fisika Berbasis eXe-learning Sebagai Penunjang Belajar Siswa Pada Pokok Bahasan Suhu dan Kalor. SNPF (Seminar Nasional Pendidikan Fisika), 0(0), Article 0. http://prosiding.unipma.ac.id/index.php/SNPF/article/view/1719

Sudjana. Nana. (2014). Dasar-Dasar Proses Belajar Mengajar. Bandung : Sinar Baru Algensindo 